Portland State University

PDXScholar

$5-24-2019$

\title{
A Consideration of Mesopredator Release and New Zealand's Predator Free Plan: a Literature Review
}

Kaitlin G. Thomas

Portland State University

Follow this and additional works at: https://pdxscholar.library.pdx.edu/honorstheses

Let us know how access to this document benefits you.

\section{Recommended Citation}

Thomas, Kaitlin G., "A Consideration of Mesopredator Release and New Zealand's Predator Free Plan: a Literature Review" (2019). University Honors Theses. Paper 704.

https://doi.org/10.15760/honors.721

This Thesis is brought to you for free and open access. It has been accepted for inclusion in University Honors Theses by an authorized administrator of PDXScholar. Please contact us if we can make this document more accessible: pdxscholar@pdx.edu. 
A Consideration of Mesopredator Release and New Zealand's Predator Free Plan:

A Literature Review

by

Kaitlin G. Thomas

An undergraduate honors thesis submitted in partial fulfillment of the requirements for the degree of

Bachelor of Science

in

University Honors

and

Biology

Thesis Adviser

Luis A. Ruedas, $\mathrm{PhD}$

Portland State University 
Table of Contents

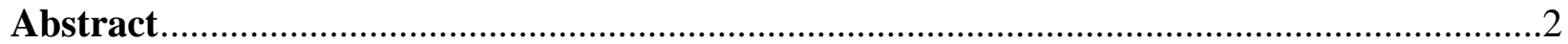

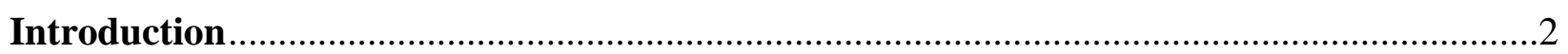

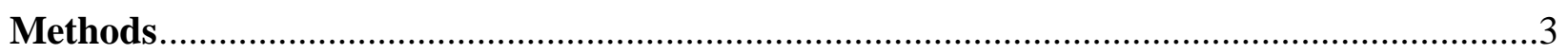

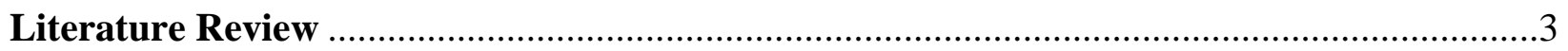

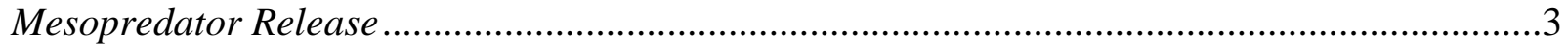

Trophic Control: Top-Down and Bottom-Up Effect ........................................................

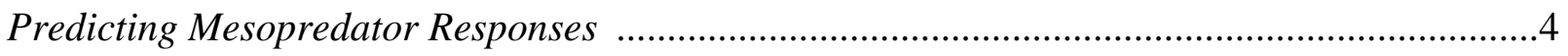

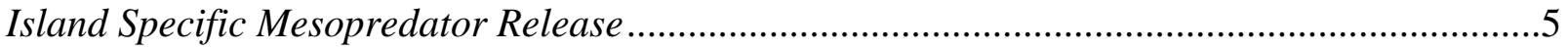

Mesopredator Release in New Zealand ...................................................................6

Linear and Triangular Interactions to Predict Cascading Effects in New Zealand ..................6

New Zealand Island Mesopredator Release ......................................................................

New Zealand Mainland Mesopredator Release ...............................................................8

Mesopredator Release Effect Informing Lethal Eradication ............................................8

Considerations before Lethal Eradication is Implemented .................................................8

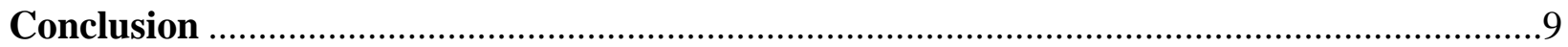

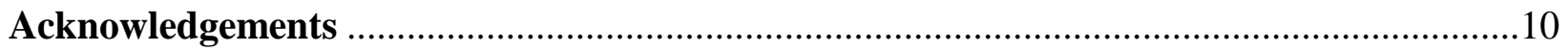

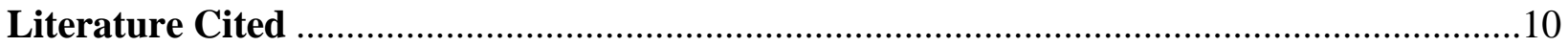




\begin{abstract}
Invasive mammalian predators are responsible for the loss of biodiversity and species extinctions worldwide: New Zealand is no exception. To protect native species, lethal eradication has become the primary means to control or remove invasive mammalian predators. These control attempts can indirectly affect non-target species through trophic interactions. Eliminating the apex predator can result in a release of lesser predators that can consequently continue causing damage, i.e., suppressing, the native prey population. This ecological interaction among trophic guilds is termed "mesopredator release." The research outlined in the present work provides a review of the concepts underlying mesopredator release, depicts how New Zealand is a suitable environment for such a release to occur, and the modifications that need to be made to lethal eradication plans make these more successful.
\end{abstract}

\title{
Introduction
}

Invasion of ecosystems by introduced species is one of the leading global causes of loss of biodiversity. In New Zealand in particular, introduced mammalian predators are actively reducing the population size of the 16 species of flightless birds that inhabit the North and South islands of New Zealand, as well as negatively affecting other native species (King, 2001). Predation by the introduced black rat (Rattus rattus) and stoat (Mustela erminea) pose the greatest risk to the native fauna (Innes 1990, Murphy \& Bradfield 1992). Other introduced predators include the common brushtail possum (Trichosurus vulpecula) native to Australia and the feral cat (Felis catus). Damage by invasive species to the New Zealand native fauna has been extensively researched over the past few decades; including damage to bat (Scrimgeour et al. 2012), bird (Bond et al. 2019), lizard (Monks et al. 2019), and fish populations (O'Donnell et al. 2017).

Total eradication of introduced mammal species on select New Zealand offshore islands has proven effective in improving island native species populations and providing a safe haven to which to transfer endangered species. The Bay of Plenty region off the North Island (ca. $37^{\circ} 37^{\prime} 51^{\prime \prime S}, 176^{\circ} 43^{\prime} 02^{\prime \prime E}$ ) hosts 18 offshore islands that have been cleared of all exotic predators and now act as protective havens for native flora and fauna (Predator-Free [no date]). With these accomplishments in mind, New Zealand has announced an initiative to be entirely predator free by 2050. The New Zealand Department of Conservation has received an initial budget of US \$ 28 million and will annually receive US \$ 7 million to fund the project (Predator Free 2016). Plans for removal of invasive species include lethal control as the primary technique. For instance, Compound 1080 (sodium fluoroacetate), a metabolic poison that does not occur naturally, is a popular and effective choice because it can be spread from the air, only targets mammals, does not bio-accumulate in soils or water, and is cost effective (NZEPA 2017).

Lethal control has been assumed to be beneficial to the biodiversity of the native flora and fauna, as observed in the eradication of exotic predators in the Bay of Plenty Region. However, these islands are closed systems of reduced area that allow for a more comprehensive distribution and implementation of lethal eradication methods over a short period of time (Bombaci et al. 2018). Attempting lethal eradication on a larger scale across the entire country will take several decades and introduces compromises to the efficacy of the technique. 
In environments affected by multiple species of long-established invasive predators, typical eradication techniques such as poisoning may not be effective in recovering the native ecosystem (Zavaleta et al. 2001, Hare et al. 2019). The food web is a delicate balance between predators and prey, and manipulation of an apex predator population can result in disruption or alteration of established trophic cascades (Tompkins \& Veltaman 2006). The removal of an apex predator species can, for example, result in the release of populations of a trophically lesser predator species. This trophic cascade is known as 'mesopredator release' and paradoxically can result in native species being more negatively impacted (Rayner et al. 2007).

Understanding potential and unexpected consequences of lethal eradication is important when attempting a large scale eradication plan such as that proposed for New Zealand (Anonymous 2000). The measure of success in a conservation project should include both absence of the invasive species and recovery of target populations (Caut et al. 2008). The questions driving the present research are: 1) What is 'mesopredator release'? 2) What concepts underlying mesopredator release play a role in New Zealand's lethal eradication of invasive mammalian predators? 3) How can the concept of mesopredator release be used to inform future lethal eradication plans? My purpose is not to provide a complete review of all the literature pertaining to the topic but to frame the concept of mesopredator release and assess the potential consequences of New Zealand's decision to lethally eradicate exotic predators.

\section{Methods}

A review of literature on the parameters of mesopredator release and its correlation with lethal eradication in New Zealand was conducted using various search engines. Key words in the searches included: mesopredator release AND New Zealand, mesopredator release AND topdown effect, mesopredator release AND feral cats, mesopredator release AND island populations, mesopredator release AND productivity. Prior to the initial search, references also were collected and reviewed from pertinent peer-reviewed articles. Resources in this thesis are from domains of Conservation Biology, Ecology, and Environmental Science.

\section{Literature Review}

\section{Mesopredator Release}

Several decades ago in the ecological field, researchers began to observe the power predators wielded over food webs, specifically: how other species were released from population control after the removal of a trophically higher predator from the ecosystem (Pacala \& Roughgarden 1984). The term 'Mesopredator Release' was used by Soulé and colleagues (1988) to describe the process whereby in the absence of large and dominant predators, smaller predators underwent population explosions. This release in turn could result in the local extinction of endangered prey species (Soulé et al. 1988). Mesopredator release can be defined as the expansion in density, expansion in distribution, or change in behavior, of a trophically mid-rank predator, due to a decline in the density or distribution of an apex predator, often at the expense of the primary prey (Brashares et al. 2010, Prugh et al. 2009, Rayner et al. 2007).

A mesopredator is defined as a mid-rank predator in the food web, independent of its size or taxonomy, within the framework of its ecosystem. An ecosystems specific food web can contain several mesopredators (Prugh et al. 2009). Importantly, a species' role in the food chain is 
dictated by the specific ecosystem they inhabit. For example, the domestic cat (Felis catus) is a mesopredator in urban environments where it is preyed upon by coyotes, but is the apex predator in many oceanic island ecosystems (Duffy \& Capece 2012). An apex predator suppresses the population of mesopredators, effectively regulating the impact these predators have on smaller prey species (Ritchie \& Johnson 2009).

\section{Trophic Control: Top-Down and Bottom-Up Effect}

There are two hypotheses that explain the population dynamics of an ecosystem: top-down control, and bottom-up control. Top-down control regulates via predation and bottom-up control regulates by prey and resource availability (Leibold et al. 1997). In systems with the potential for mesopredator release, the food web is regulated by top-down control. In the elimination of topdown control, two species from the same trophic level compete for the same resources in the absence of an apex predator (Elmhagen \& Rushton 2007). A mathematical model can be used to create a two-species competition model, with the assumption that one species is competitively superior to the other. The model demonstrates that removal of one species will result in the release of the other species at the same trophic level. For example, if the superior competitor is under control, the inferior, uncontrolled, competitor may dramatically increase in numbers. If a sudden increase in predator population numbers exceeds the sustainability of the prey, damage to the prey population can be substantial. In addition, the model demonstrates that if both superior and inferior competitors were under control, the inferior competitor would still increase. Competitor release is particularly damaging for prey species when the inferior competitor has a higher affinity for the shared prey (Caut et al. 2007).

\section{Predicting Mesopredator Responses}

Intraguild predation is the function of mesopredator suppression by apex predators, defined as the "killing and eating of species that use similar, often limiting, resources and are thus potential competitors" (Polis et al. 1989, Prugh et al. 2009). As a result, an apex predator may kill for two reasons: a) food; or b) elimination of competition. Population pressure applied by the apex predator results in both behavioral and habitat changes in the mesopredator (Ritchie \& Johnson 2009). Consequently, there are two factors that influence the strength of mesopredator release: a) species diversity; and b) the productivity of the system (Brashares et al. 2010). In low productivity ecological systems, it is predicted that the apex predator could potentially become extinct and mesopredators become limited by prey availability (Prugh et al 2009). In more and highly productive systems, it is predicted that the apex predator would thrive due to the high availability of resources and the stability of the mesopredator population. If the apex predator is removed from a highly productive system, the result will be a strong mesopredator release. For example, when a red fox, Vulpes vulpes (mesopredator) population was observed in response to a decline in population numbers of wolves, Canis lupus (apex predator), it was found that the greatest mesopredator release occurred in areas of high productivity (Elmhagen \& Rushton, 2007). In areas of high productivity, top-down control is therefore increasingly important in regulating mesopredator outbreaks. It is important to note that when both top-down and bottomup control is relaxed, there is potential for an explosion of mesopredator growth (Prugh et al. 2009).

In areas of high species diversity that host complex trophic webs, removal of an apex predator will have limited effects. In contrast, in areas of low species diversity, removal of an apex 
predator can potentially result in very strong mesopredator release; this is most commonly observed in island ecosystems (Rayner et al. 2007).

\section{Island Specific Mesopredator Release}

The strongest mesopredator effect will occur in areas of low species diversity, islands are particularly susceptible and can experience an amplification of negative effects on primary prey species. Mesopredator release on an island can be examined mathematically using a threespecies model: prey-mesopredator-apex predator. This model can be contextualized using a population of bird (prey), rat (mesopredator), and feral cat (apex predator). The model uses a set of variables to represent population ( $B$ [ird], $R$ [at], $C$ [at]), intrinsic growth rate $\left(r_{B}, r_{k}, r_{c}\right)$, predation rate of the apex predator on the prey $\left(\mu_{b}\right)$ and on the mesopredator $\left(\mu_{r}\right)$, the predation rate of the mesopredator on the prey $\left(\eta_{b}\right)$ and on other food items $\left(\eta_{s}\right)$, carrying capacity $K_{b}$, and non-avian food $(\mathrm{S})$. The model assumes that the apex predator preys on both the mesopredator and the prey. Equations one, two, and three, represent the standard relationships among the three species on a given island.

$$
\begin{gathered}
\frac{d B}{d t}=r_{b} B\left(1-\frac{B}{K_{b}}\right)-\frac{B}{S+B} \eta_{b} R-\frac{B}{B+R} \mu_{b} C \\
\frac{d R}{d t}=r_{r} R\left(1-\frac{\eta_{b} \eta_{s} R}{\eta_{b} S+\eta_{s} B}\right)-\frac{R}{B+R} \mu_{r} C \\
{[3] \quad \frac{d C}{d t}=r_{c} C\left(1-\frac{\mu_{b} \mu_{r} C}{\mu_{r} B+\mu_{b} R}\right)}
\end{gathered}
$$

Using these equations, it can be concluded that: a) the rat population alone is capable of eradicating the bird population but the cat is not; and $b$ ) when both cat and rat populations are present, the cat protects the bird population by controlling or eradicating the rat population. When a control effort is applied to the rat population $\left(\lambda_{r}\right)$ and to the cat population $\left(\lambda_{c}\right)$, the models change:

$$
\begin{gathered}
\text { [4] } \frac{d B}{d t}=r_{b} B\left(1-\frac{B}{K_{b}}\right)-\frac{B}{S+B} \eta_{b} R-\frac{B}{B+R} \mu_{b} C \\
\text { [5] } \frac{d R}{d t}=r_{r} R\left(1-\frac{\eta_{b} \eta_{s} R}{\eta_{b} S+\eta_{s} B}\right)-\frac{R}{B+R} \mu_{r} C-\lambda r R \\
\text { [6] } \quad \frac{d C}{d t}=r_{c} C\left(1-\frac{\mu_{b} \mu_{r} C}{\mu_{r} B+\mu_{b} R}\right)-\lambda c C
\end{gathered}
$$

Models three, four, and five, demonstrate that with high enough control, cat populations can be eradicated. This in turn results in prey disappearing if the rat population is not under sufficient control from predation. The models also demonstrate that when there is limited control on the cat population, the prey will not go extinct if the rat population is under strong enough population constraint. This supports the theory that the presence of the apex predator can indirectly protect a shared prey source from the mesopredator (Courchamp et al. 1999). Although rats prey on birds less than cats do, a sudden release of the rat population could cause an increase in pressure on 
prey (Newman \& McFadden 1990). This model demonstrates the need for careful control of apex predators in island ecosystems.

\section{Mesopredator Release in New Zealand}

\section{Linear and Triangular Interactions to Predict Cascading Effects in New Zealand}

To understand interactions among predators, mesopredators, and prey, in New Zealand, a triangular structure must be used. Triangular interactions results in shared predation on the same prey species, in this case birds in New Zealand. For mesopredator release to be detected, the mesopredator must exceed and replace the predation of the apex predator (Prugh et al. 2009). Mesopredators tend to be more efficient predators than apex predators, and in New Zealand's case, there are numerous mesopredators at the same trophic level. Feral cats and stoats are carnivorous and opportunistic hunters while possum, rat, and mouse, are omnivores. As omnivores, the mesopredators can maintain increased pressure on the prey species even when prey population is low (Courchamp et al. 1999).

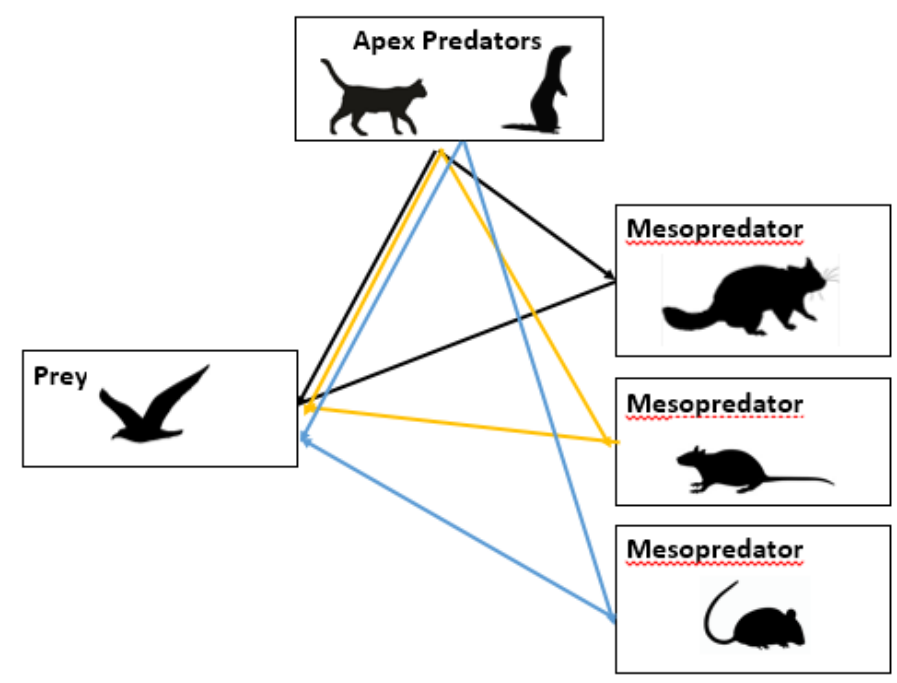

Figure 1. Triangular interactions on mainland New Zealand. Apex predators are (left to right) feral cat (Felis catus) and stoat (Mustela erminea). Mesopredators are (top to bottom), common brushtail possum (Trichosurus vulpecula) native to Australia, and rats (Rattus rattus) and mice (Mus musculus) native to Eurasia. Not shown are similar triangular interactions among mesopredators and prey.

Figure 1 demonstrates the multiple triangular interactions within the trophic structure of a potential trophic web in New Zealand. It may take a substantial loss of prey to initiate a signal of mesopredator release. For example, when a stoat population was removed from central north New Zealand, there lacked evidence of a strong mesopredator release of mice or rats (Ruscoe $e t$ al. 2011). This result suggests that the rat and mouse population may have increased, but were unable to carry out predation at levels equivalent to those of the apex predator, causing the mesopredator release to go unnoticed. With additional prey species under a regime of population monitoring, e.g., lizards and insects, cascading mesopredator effects could potentially be detected sooner (Prugh et al. 2009). In contrast, there may be only one triangle formation 
representing interaction between species on islands or in areas of low species diversity. For example, on Little Barrier Island, centered ca. 36 $12^{\prime} 06$ 'S, $175^{\circ} 04^{\prime} 52^{\prime \prime} \mathrm{E}$, in the Hauraki Gulf off the north coast of the North Island of New Zealand, there is a single triangle describing the relationships among cat, rat, and bird. (Rayner et al. 2007).

\section{New Zealand Island Mesopredator Release}

On several islands off the coast of New Zealand, the consequences of eradication of apex predators have been made obvious. On Little Barrier Island, Rayner and colleagues (2007) used the invasive cat (predator) and rat (mesopredator) population to test the effect of mesopredator release on the native Cook's petrel (Pterodroma cookii) population over a 32 year span. In the presence of both cat and rat populations, a baseline number for chicks per burrow was recorded. It was found that upon cat eradication, the increased rat population caused a decrease in the number of chicks per burrow, demonstrating that eradication of the apex predator was detrimental to the native prey species (Rayner et al. 2007).

It is not unusual to find that removing feral cats from island ecosystems is potentially detrimental to prey species. In another study, on Stewart Island (centered ca. 4700'28"S, 16752'36"E, off the south coast of the South Island) the effects of feral cats on the native kakapo parrot (Strigops habroptilus) population were observed. Of the 118 feline scat samples collected, only $5.1 \%$ contained remains of kakapo, whereas $93 \%$ contained rat remains. The ratio of kakapo to rat found in the scat suggest that removing the feral cat population could increase damage to the kakapo population. This evidence was supported by the island mesopredator mathematical model that suggested that eradication of cats and limited control of rats would result in a decline in the numbers of kakapo (Courchamp et al. 1999).

A previous study by Fitzgerald et al. (1991) also had determined that feral cat eradication may not be the most effective approach for preserving bird species in island populations. On Raoul Island, centered ca. $2^{\circ} 16^{\prime} 02^{\prime \prime S}, 177^{\circ} 55^{\prime} 30^{\prime \prime} \mathrm{W} 1000 \mathrm{~km}$ northeast of New Zealand, rats and cats live together sharing a varied avian prey base. Together, they have caused devastation to the seabird population. After trapping and testing stool samples of the feral cats, it was observed that the cat population does not kill a significant number of birds but rather that their diet was primarily composed of rats. It was determined that the removal of cats from the island would result in an increase in the rat population and continued devastation to the seabird population (Fitzgerald et al. 1991). Eradication of the rat population would however likely lead to a shift in the cats' prey base, to seabirds, so the results of that study should be viewed with caution.

Cats are not the only predator capable of causing a mesopredator release. It has been found in many New Zealand islands that the eradication of rats can cause a release of mice, $M u s$ musculus. Mouse populations tend to be smaller than rat populations, but there is evidence of them greatly expanding their numbers in the absence of rats. Removal of rats can cause a mesopredator release of mice because rats both outcompete and prey upon mice (Caut et al. 2007). In some cases, mouse populations were undetectable until a rat population had been eradicated. This has been the case on several New Zealand islands, including Quail Island (centered at $43^{\circ} 37^{\prime} 41^{\prime \prime} \mathrm{S}, 172^{\circ} 41^{\prime} 25.5^{\prime \prime} \mathrm{E}$, in Charteris Bay, on the east coast of the South Island), where mice have overcome two eradication campaigns (Bowie et al. 2018). In addition, it was found that the stronger the control of rats, the larger became the final population of mice (Caut $e t$ al. 2007). 


\section{New Zealand Mainland Mesopredator Release}

There has been limited research on mesopredator release on the mainland of New Zealand and limited research on how trophic cascades are affected by the eradication of its constituent species. Stoats and feral cats share the title of apex predator in the New Zealand ecosystem; however, with a larger body size, feral cats tend to be the dominant predator. In a study on stoat behavior in response to the presence of feral cats, it was found that stoats altered their foraging behavior in response to perceived competition, avoiding areas of potential high risk. This suggests that these two apex predators do not overlap their habitat, an important factor in potential competitor release. If the feral cat was eradicated, the stoat could fill the niche left open due to reduced competition. Depending on the prey type, this could have detrimental effects on native populations (Garvey et al. 2015).

In addition, there has been research carried out on the central North Island on the effect of removing a stoat population from a controlled environment. The investigators found that there was not a significant increase in rat population after the removal of stoats. At the time of the experiment, the environment was in a period of low productivity due to it not being a masting year, when trees produce large number of fruit (Ruscoe et al. 2011). During masting years, rat and mice populations increase due to food availability (Jones et al. 1998, Tompkins \& Veltaman 2006). The low productivity, consistent with the models, resulted in lack of observation of a mesopredator release. However, during the same year, possum populations were experimentally removed and rat populations increased. In the region of the experiment, the latter two species share 55\% prey type and do not prey on each other. This is evidence of the possum population outcompeting the rat population for shared food sources. The rat population increase was exacerbated by it being a non-masting year (Ruscoe et al. 2011).

\section{Mesopredator Release Effect Informing Lethal Eradication}

\section{Considerations before Lethal Eradication is Implemented}

Although lethal eradication can often be successful at eliminating a target species, the removal of the target species is not the only measure of success. The measure of success in a conservation project should include the absence of the invasive species and the recovery of target populations (Caut et al. 2008). It has been demonstrated that mesopredator release is a complex and potentially dangerous in its effect on native prey species. If lethal eradication is to be the primary conservation tool, there should be distinct phases of pre- and post-eradication.

In the pre-eradication phase, the target location should first have a detailed outline characterized describing the relationships among distinct trophic levels in the ecosystem (Caut et al. 2007). Specifically, the evaluation should first include a qualitative assessment of the trophic interactions between both native and exotic species. Secondly, the evaluation should include an assessment of the functional roles of exotic species in the ecosystem (Zavaleta et al. 2001). An example would be outlining the current impact of rats on local bird populations. This latter evaluation could result in insights on the damage that may occur in the chance of a mesopredator release (Caut et al. 2008). By performing a pre-eradication assessment, a plan could be created to strategically target populations simultaneously or in a stepwise fashion. For example, Fitzgerald et al. (1991) showed that, on Raoul Island, eradication of cats would result in an 
increase in the rat population with detrimental effects on the bird population. However, eradication of rats, the cats' preferred prey base, would merely cause a shift in prey base onto seabirds. A sequential or careful combined eradication program might achieve more beneficial results without detrimental effects on seabird populations.

The benefit of pre-eradication planning was supported in a study on Macquarie Island, an Australian island located between New Zealand and the Antarctic, centered ca. 54 $37^{\prime} 21$ "S, $158^{\circ} 52^{\prime} 07^{\prime \prime} \mathrm{E}$. Here, researchers performed qualitative modelling of the ecosystem to account for potential consequences of invasive species removal involving rabbits, rats, and mice. Based on the modelling results, it was determined that equal targeting of all three non-native pest species would be most effective, but that eradication of the mouse population had a high level of uncertainty (Raymond et al. 2011). With this plan established, a more effective and comprehensive eradication period could ensue.

In addition, it is important to consider the most effective lethal eradication technique for the target species. In a Costa Rican study, it was found that mosquito (genus Wyeomyia) population size doubled due to an evolved resistance to a pesticide that is eradicating their top predator, damselfly larvae (Mecistogaster modesta). Though both invertebrate populations were targeted for eradication, the resistance allowed a mesopredator release of $W$. abebela (Weathered et al. 2019). The results stress the importance in understanding how specific eradication techniques affect targeted species in order to avoid an unintentional mesopredator release. With these types of comprehensive plans, mesopredator release and other consequences of lethal eradication can be limited or predicted.

In the post-eradication phase, there should be a reevaluation of the timing and method of lethal eradication. This post-eradication phase could yield valuable insights into the effectiveness of the plan. For example, in one New Zealand study, it was found that the simultaneous removal of rabbits and cats maximized the native bird success. The authors also determined if one species had to be targeted first, rabbits should take initial priority (Zavaleta et al. 2001). In other studies, it has been suggested if all the invasive species cannot all by targeted simultaneously, it is best to target the trophically most inferior invasive predator first (Caut et al. 2008). It is important to accurately assess tropic interactions because models that replicate release from top-down control recognize highly specific control as an optimum choice to avoid accidental by-kill. However, it does increase the risk for release of competitors from the same trophic level.

\section{Conclusion}

New Zealand's intensive plan for lethal eradication calls for a pause to evaluate the high potential for mesopredator release and negative consequences on native species. Lethal eradication of apex predators has been determined to be responsible for the release of lesser predator populations. Through mathematical modeling of varying ecosystems and ecological scenarios, it has been found that mesopredator release can be more detrimental to the prey population than the prior removal of apex predators. Island populations of indigenous species are particularly at risk because of their low species diversity and limited geographic range; New Zealand and its offshore islands are no exception. The current lethal eradication planning prior to implementation in New Zealand is simple, with success of operation based solely on kill rates of targeted species rather than improvement in the prey species population. By implementing a pre- 
eradication plan that characterizes the ecosystem of interest and looks for trophic level interactions, New Zealand could provide substantially more protection to their species of interest. New Zealand is under pressure to quickly and efficiently eliminate invasive mammalian predators, but if a change is not made to the process of lethal eradication, the country could see native species go extinct in their attempt to provide relief.

\section{Acknowledgments}

I would like to express my gratitude to my thesis advisor, Dr. Luis A. Ruedas, Professor of Biology, Portland State University, for his expert guidance during the development and culmination of this undergraduate thesis.

\section{Literature Cited}

Anonymous. 2000. New Zealand Biodiversity Strategy 2000-2020. New Zealand Department of Conservation, $144 \mathrm{pp}$.

Bombaci, S., Pejchar, L. \& Innes, J. 2018. Fenced sanctuaries deliver conservation benefits for most common and threatened native island birds in New Zealand. Ecosphere, 9(11): e02497. https://doi.org/10.1002/ecs2.2497.

Bond, A.L., Brooke, M.DL, Cuthbert, R.J., Lavers, J.L., McClelland, G.T.W., Churchyard, T., Donaldson, A., Duffield, N., Forrest, A., Harrison, G., MacKinnon, L., Proud, T., Skinner, A., Torr, N., Vickery, J.A. \& Oppel, S. 2019. Population status of four endemic land bird species after an unsuccessful rodent eradication on Henderson Island. Bird Conservation International, 29(1):124-35. https://doi.org/10.1017/S0959270918000072.

Bowie, M.H., Corodji, J.M., Ford, D., Ross, J.G., McLennan, I., Fewster, R.M., \& Murphy, E.C. 2018. Mouse management on Ōtamahua/Quail Island-lessons Learned. New Zealand Journal of Zoology, 45(3):267-85. https://doi.org/10.1080/03014223.2018.1482929.

Brashares, J.S., Prugh, L.R., Stoner, C.J. \& Epps, C.W. 2010. Ecological and conservation implications of mesopredator release. Pp. 221-33 in: Tophic Cascades: Predators, Prey, and the Changing Dynamics of Nature (Terborgh, J., and J. A. Estes eds.). Washington, D. C., Island Press, 488 pp.

Brown, K. P., Moller, H., Innes, J. \& Alterio, N. 1996. Calibration of tunnel tracking rates to estimate relative abundance of ship rats (Rattus rattus) and mice (Mus musculus) in a New Zealand forest. New Zealand Journal of Ecology, 20(2):271-275.

Caut, S., Angulo, E. \& Courchamp, F. 2008. Avoiding surprise effects on Surprise Island: alien species control in a multitrophic level perspective. Biological Invasions, 11(7):1689-1703. https://doi.org/10.1007/s10530-008-9397-9.

Caut, S., Casanovas, J.G., Virgos, E., Lozano, J., Witmer, G.W. \& Courchamp, F. 2007. Rats dying for mice: modelling the competitor release effect. Austral Ecology, 32(8):858-868. https://doi.org/10.1111/j.1442-9993.2007.01770.x. 
Courchamp, F., Langlais, M. \& Sugihara, G. 1999. Cats protecting birds: modelling the mesopredator release effect. Journal of Animal Ecology 68(2):282-92. https://doi.org/10.1046/j.1365-2656.1999.00285.x.

Duffy, D. C. \& Capece, P. 2012. Biology and impacts of Pacific island invasive species. 7. The domestic cat (Felis catus). Pacific Science, 66(2):173-212. https://doi.org/10.2984/66.2.7.

Elmhagen, B. \& Rushton, S. P. 2007. Trophic control of mesopredators in terrestrial ecosystems: top-down or bottom-Up? Ecology Letters 10(3):197-206. https://doi.org/10.1111/j.1461-0248.2006.01010.x.

Fitzgerald, B., Karl, B.J. \& Veitch, C.R. 1991. The diet of feral cats (Felis catus) on Raoul Island, Kermadec Group. New Zealand Journal of Ecology, 15(2):123-129.

Garvey, P., Glen, A. \& Pech, R. 2015. Foraging ermine avoid risk: behavioural responses of a mesopredator to its interspecific competitors in a mammalian guild. Biological Invasions, 17(6):1771-83. https://doi.org/10.1007/s10530-014-0833-8.

Hare, K. M., Borrelle, S.B., Buckley, H.L., Collier, K.J., Constantine, R., Perrott, J.K., Watts, C.H. \& Towns, D.R. 2019. Intractable: species in New Zealand that continue to decline despite conservation efforts. Journal of The Royal Society of New Zealand, Published online 14 Apr 2019. doi: 10.1080/03036758.2019.1599967

Innes, J. G. 1990. Ship rat. Pp. 206-225, in: The handbook of New Zealand mammals (King, C. M. ed). Auckland, New Zealand, Oxford University Press.

Jones, C. G., Ostfeld, R.S., Richard, M.P., Schauber, E.M. \& Wolff, J.O. 1998. Chain reactions linking acorns to Gypsy Moth outbreaks and Lyme Disease risk. Science, 279(5353):1023-1026, doi: 10.1126/science.279.5353.1023

King, C. M. 2001. Advances in New Zealand mammalogy, 1990-2000: Introduction. Journal of the Royal Society of New Zealand, 31(1):1-5, doi:10.1080/03014223.2001.9517634

Leibold, M. A., Chase, J.M., Shurin, J.B. \& Downing, A.L. 1997. Species Turnover and the Regulation of Trophic Structure. Annual Review of Ecology and Systematics, 28:467-94.

Monks, J. M., Nelson N.J., Daugherty, C.H., Brunton D.H. \& Shine, R. 2019. Does Evolution in Isolation from Mammalian Predators Have Behavioural and Chemosensory Consequences for New Zealand Lizards." New Zealand Journal of Ecology 43(1):3359. https://doi.org/10.20417/nzjecol.43.10.

Murphy, E. \& Bradfield, P. 1992. Changes in diet of stoats following poisoning of rats in a New Zealand forest. New Zealand Journal of Zoology 16: 137-140.

New Zealand Environmental Protection Agency. 2017. EPA annual report on aerial use of 1080.”, December 31, 2017.

Newman, D. G. \& McFadden, I. 1990. Seasonal fluctuations of numbers, breeding, and food of kiore (Rattus exulans) on Lady Alice Island (Hen and Chickens group), with a consideration of kiore: tuatara (Sphenodon punctatus) relationships in New Zealand. New Zealand Journal of Zoology, 17(1):55-63.

O’Donnell, C. F. J., Weston, K.A. \& Monks, J.M. 2017. Impacts of introduced Mammalian predators on New Zealand's Alpine Fauna. New Zealand Journal of Ecology 41(1):1-22. https://doi.org/10.20417/nzjecol.41.18.

Pacala, S. \& Roughgarden, J. 1984. Control of arthropod abundance by Anolis lizards on St. Eustatius (Neth. Antilles). Oecologia 64(2):160-62. 
Polis, G. A., Myers, C.A. \& Holt, R.D. 1989. The ecology and evolution of intraguild predation: potential competitors that eat each other. Annual Review of Ecology and Systematics, 20:297-330.

Predator Free 2050. [no date]. Predator-free offshore islands in the Bay of Plenty Conservancy. https://www.doc.govt.nz/nature/pests-and-threats/predator-free-2050/. Retrieved November 19, 2018.

Prugh, L. R., Stoner, C.J., Epps, C.W., Bean, W.T., Ripple, W.J., Laliberte, A.S. \& Brashares, J.S. 2009. The rise of the mesopredator. BioScience 59(9):779-91. https://doi.org/10.1525/bio.2009.59.9.9.

Raymond, B., McInnes, J., Dambacher, J.M., Way S. \& Bergstrom, D.M. 2011. Qualitative modelling of invasive species eradication on subantarctic Macquarie Island. Journal of Applied Ecology, 48(1):181-91, doi: 10.1111/j.1365-2664.2010.01916.x

Rayner, M. J., Hauber, M.E., Imber, M.J., Stamp, R.K. \& Clout, M.N. 2007. Spatial heterogeneity of mesopredator release within an oceanic island system. Proceedings of the National Academy of Sciences, 104(52):20862-65. https://doi.org/10.1073/pnas.0707414105.

Ritchie, E. G. \& Johnson, C.N. 2009. Predator interactions, mesopredator release and biodiversity conservation. Ecology Letters, 12(9):982-98. https://doi.org/10.1111/j.14610248.2009.01347.x.

Ruscoe, W. A., Ramsey, D.S.L., Pech, R.P., Sweetapple, P.J., Yockney, I., Barron, M.C., Perry, M., Nugent, G., Carran, R., Warne, R., Brausch, C. \& Duncan, R.P. 2011. Unexpected consequences of control: competitive vs. predator release in a four-species assemblage of invasive mammals. Ecology Letters 14(10):1035-42. https://doi.org/10.1111/j.1461-0248.2011.01673.x.

Scrimgeour, J., Beath, A. \& Swanney, M. 2012. Cat predation of short-tailed bats (Mystacina tuberculata rhyocobia) in Rangataua Forest, Mount Ruapehu, Central North Island, New Zealand. New Zealand Journal of Zoology, 39(3):257-260. doi:10.1080/03014223.2011.649770

Soulé, M. E., Bolger, D.T., Alberts, A.C., Wright, J., Sorice, M. \& Hill, S. 1988. Reconstructed dynamics of rapid extinctions of Chaparral-requiring birds in urban habitat islands. Conservation Biology 2(1):75-92.

Tompkins, D. M., \& Veltman, C.J. 2006. Unexpected Consequences Of Vertebrate Pest Control: Predictions From A Four-Species Community Model." Ecological Applications 16(3):1050-61. https://doi.org/10.1890/1051-0761(2006)016[1050:UCOVPC]2.0.CO;2.

Weathered ,J., Hammill, E. 2019. Adaptation to agricultural pesticides may allow mosquitoes to avoid predators and colonize novel ecosystems. Oecologia 190:219-227. doi: 10.1007/s00442-019-04403-2.

Zavaleta, E. S., Hobbs, R.J. \& Mooney, H.A. 2001. Viewing Invasive Species Removal in a Whole-Ecosystem Context." Trends in Ecology \& Evolution 16(8):454-59. https://doi.org/10.1016/S0169-5347(01)02194-2. 
